\title{
THE ROLE OF INQUIRY APPROACH AND COGNITIVE STAGE ON STUDENT'S MATHEMATICAL CRITICAL THINKING ABILITY AND SELF REGULATED LEARNING
}

\author{
Nana Sukarna ${ }^{1}$, Utari Sumarmo' ${ }^{2}$, Rudi Kurniawan ${ }^{3}$ \\ 1,2,3 IKIP Siliwangi \\ 1'nasukarna@yahoo.co.id, ${ }^{2}$ utari.sumarmo@gmail.com, ${ }^{3}$ rudikurniawan858@yahoo.com
}

Received: April, 2020; Accepted: July, 2020

\begin{abstract}
The goal of this research is to analize the role of inquiry approach (IA) and cognitive stage (CS) on students'mathematical critical thinking ability (MCTA) and self regulated learning in mathematics (MSRL). The research adopted a pretest and postest design and involved 60 eleventh grade students of 16 - 18 years old, a MCTA test, the TOLT, and Longeot test, and a MSRL scale, and student's opinion on IA lessons. The study revealed that percentage of student' CS, were as follow $11.7 \%$ at concrete stage, $65.0 \%$ at transition stage, and $23.3 \%$ at formal stage. In further analysis the study found that IA and CS took a good role on obtaining student's MCTA, but not for MSRL. The for mal operational stage students obtained higher grades on MCTA than the transitional and concrete operational stages, conversely the concrete operational stage students obtained higher grades on MSRL than the formal and transitional operational. Students taught by saintific approach (SA) realized more difficulties in solving MCTA tasks than students getting treatment with IA. The study also found 1) MCTA students whose learning with IA is better than SA at medium grade level 2) no association between MCTA and CS, MCTA and MSRL, and CS and MSRL. Beside that, students performed intense activities during the IA lessons such as to discuss acitvely, to solve problems enthutiastically, and to present their work in front of the class voluntary.
\end{abstract}

Keywords: mathematical critical thinking abilitty, self regulated learning, inquiry approach, cognitive stage

\begin{abstract}
Abstrak
Penelitian ini bertujuan menganalisis peran pendekatan inkuiri (IA) dan tahap kognitif (CS) terhadap kemampuan berpikir kritis matematis (MCTA) siswa dan pembelajaran mandiri dalam matematika (MSRL). Penelitian ini mengadopsi desain pretest dan postest dan melibatkan 60 siswa kelas sebelas usia 16 - 18 tahun, tes MCTA, tes TOLT, dan Longeot, dan skala MSRL, serta pendapat siswa tentang pelajaran IA. Hasil penelitian menunjukkan bahwa persentase CS siswa adalah 11,7\% pada tahap konkrit, $65,0 \%$ pada tahap transisi, dan 23,3\% pada tahap formal. Dalam analisis lebih lanjut, studi menemukan bahwa IA dan CS mengambil peran yang baik dalam memperoleh MCTA siswa, tetapi tidak untuk MSRL. Siswa tahap operasional formal memperoleh nilai yang lebih tinggi pada MCTA dibandingkan pada tahap operasional transisi dan konkrit, sebaliknya siswa tahap operasional konkret memperoleh nilai yang lebih tinggi pada MSRL dibandingkan pada tahap operasional formal dan transisi. Siswa yang diajar dengan pendekatan saintific (SA) menyadari lebih banyak kesulitan dalam menyelesaikan tugas MCTA daripada sisw a yang mendapatkan perlakuan dengan IA. Penelitian ini juga menemukan 1) MCTA siswa yang pembelajarannya dengan IA lebih baik daripada SA dengan kriteria sedang 2) tidak ada hubungan antara MCTA dan CS, MCTA dan MSRL, dan CS dan MSRL. Selain itu, siswa juga melakukan aktivitas intensif selama pembelajaran IA seperti berdiskusi secara aktif, memecahkan masalah secara antusias, dan mempresentasikan hasil karyanya di depan kelas secara sukarela.
\end{abstract}

Kata Kunci: kemampuan berpikir kritis matematis, self regulated learning, pendekatan inkuiri 
How to Cite: Sukarna, N., Sumarmo, U., \& Kurniaw an, R. (2020 The Role of Inquiry Approach and Cognitive Stage on Student's Mathematical Critical Thinking Ability and Self Regulated Learning. Journal Of Educational Experts (JEE) 3 (2), 74-86.

\section{INTRODUCTION}

A member of researchers of this study is a mathematics teacher of a senior high school in Bandung. Based on researchers observation and teacher's experience during mathematics lessons in 2018-2019, we obtained impression there were many students failed to exmine the truth of calculation processes of a non rutine mathematics problem, they avoided math tasks which asking rules or principles underlied in each step of completing task, and they failed to examine the truth of a statement. Other our impression was: students performed positive learning disposition such as manage their learning time and compare their grades with the standards set by the school. The first situation pointed out of students with low mathematical critical thinking ability (MCTA), while second condition described the situation of students who have the ability to organize themselves in learning. The last statement related to the term mathematical self regulated learning (MSRL). We understand that MCTA and MSRL are essential learning outcomes that should be owned by high school students. The reason underlied the statement is not only MCTA is attached in the goal of mathematics teaching (Indonesia Mathematics Curriculum, 2013), but also in line with expert opinion, namely: When student think critically, he will solve any problem effectively, he rejects statement without examining its truth, and he is responsible in solving problem by giving rational reasons (Peter, 2010, 2012).

There are some MCTA notions among other are: a. Critical thinking ability is ability to exmine an idea accompanied with responsible reason (Fisher, 1995); b. Critical thinking ability is reasonable reflective thinking and ability to deduce conclussion based on trusted arguments (Ennis, as cited in Baron, \& Sternberg, (Editor), 1987, and Hassoubah, 2004). When we observe deeply the processess involved in MCTA, we inffer that MCTA tasks involve higher order thinking (HOT) mathematics processes, so that for solving MCTA tasks, students should master the mathematics content and processes, accompanied with strong MSRL and they should have cognitive learning readiness. Some experts (Butler, 2002, Hargis and Kerlin, 1992, Schunk and Zimmerman, 1998, as cited in Sumarmo, 2006), define SRL in different expressions, but they involve similar traits, such as: to manage self learning objective; to prefer strategy; and to observe and to assess, learning outcomes, and to compare them to a certain standard.

In line with the term of cognitive learning readiness our discussion related to a kind of thinking such as formal operational thinking ability. Inhelder and Piaget (1972, as cited in Sumarmo, 2019) by analyzing deeply the way of thinking of various groups of chidren, they catagorized children' thinking ability into four main stages namely: a) Sensory-motor stage (infant up to 2 years old); b) Pre-concrete operational stage $(2-7$ years old); c) Concrete operational stage (7-12 years old); d) formal operational stage (13-14 years old or 14-15 years old). Later, Tobin and Capie (1982, as cited in Sumarmo, 2019) constructed a group test calle d TOLT and Sheehan (as cited in Sumarmo, 2019) to to measure cognitive stage of student's thinking based on Piaget's theory.

Polya (1975) explains that mathematics teacher's task is not only to deliver mathematics content but the more important tasks are: to take sides on student's hope, to respect to student's thinking, to support student to obtain a new understanding, to promote student's reasoning ability, to motivate student to present their ideas in their words, and to motivate student to think well. Besides that, Indonesia mathematics curriculum, 2013, suggests that mathematics ability and affective behaviour such as MCTA and MSRL should be developed 
run together. After researchers take up some teaching aproaches, we predict inquiry approach (IA) will suitable with both afformentioned suggestions.

Inquiry approach (IA) is a teaching approach that invested basic scientific thinking on students. In this approach, students are motivated to learn by themselfes, to develop their creativity on solving problem. Sagala (2004) clarifies that in IA, students as learning subyect and teacher as conselor and fasilitator. Teacher's task is to sellect relevant problem to solve by students or students are allowed to sellect or to compile problems by themselfes.

Up this moment, there were some studies examined student's MCTA and MSRL and carried out IA approach separately. For examples, recent limited studies (Damayanti, Sumarmo, Maya, 2018, Wardani, Sumarmo, Nishitani, 2011) by implementing inquiry approach (IA) reported students obtained reasoning and creative thingking abilities at medium grade level. However, many other studies (Kurniawati, Kusumah, Sumarmo, Sabandar, 2014, Nurina, 2014, Murni, Sugandi., 2018, Retnaningsih, Sugandi, 2018, Widyaningtias, Kusumah, Sumarmo, Sabandar, 2017) by applying variety of teaching approaches found that students obtained MCTA at medium grade level. As well as, other studies (Aminah, Kusumah, Suryadi, and Sumarmo,2018, Romlah, Sumarmo, Syaban, 2018, Krisnawati, Rohaeti, Maya, 2018, Retnaningsih, Sugandi, 2018) reported that students attained MSRL at fairly good grade level. Seemingly, for students it was more difficult to solve MCTA tasks than to behave MSRL.

Those afformentioned arguments and findings stimulate researchers to excecute a study to analyze the role of MCTA and student's cognitive stage, on obtaining student's MCTA, and MSRL and then we compile research questions as follow.

1. What are percentage of student's cognitive stage measured by using TOLT and the Longeot test?

2. Are MCTA grade and its normalized gain, and MSRL grade of students getting treatment with IA better than the grades of students taught by SA?

3. What are student's difficulties on solving MCTA tasks?

4. Is there any association between MCTA and MSRL?

5. What are student's activities during IA lessons?

\section{THEORITICAL REVIEW}

\section{Mathe matical Critical Thinking Ability, Self Regulated Learning in Mathe matics, and Cognitive Stage}

In addition to afformentioned reasons that MCTA should be improved on high school students, there are other motives namely: a. When student thinking critically, mathematical content is transformed into mathematical thinking (Lunenburg, 2011); b. A critical thinker tends to behave carefully in taking decision, to confess foolishness fastly, to get new information eagerly, to be patient in investigating a proof, to be tolerant on new viewpoint, and to confess the better viewpoint of other people (Johnson, 2007); c. Student who think critically among other will tend to evaluate the truth of recieved information, to think self-reliantly, and he will be responsible toward his opinion accompanied with logical reasoning (Anderson, as cited in Lestari, 2013),

Further, besides the notion of critical thinking ability (CTA) have been described, some writers propose other notions of CTA in different expression, namely: a. Critical thinking is processes analyzing, explaining, developing, and selecting ideas. It covers to classify, to compare, to contrust, to test argument and asumption, to evaluate induction and deduction, to determine priority and choice (Gokhale, 1995); b. Critical thinking ability is ability to give an organized reason and to evaluate the quality of a reason systimatcally. (Hassoubah, 2007); c. Critical thinking is a directed and definited process in solving problem, deriving conclusion, analyzing assumption, and executing scientific research (Yohnson, 2007); d. Mathematical critical thinking includes ability and disposition and they are combined with prior knowlgde, 
mathematical reasoning, and cognitive strategy for generalyzing, proving, and evaluating mathematical situation reflectively (Glazer, 2004).

With regard to SRL, some authors define it more detail as follow: a. SRL is to design and to observe self learning process carefully in completing an academic task (Hargis and Kerlin, 1992); b. SRL is habit to observe self behaviour such as to assess own-self, to determine learning goal and conception; to accustome to work hard (Bandura as cited in Hargies, and Kerlin, 1992), c. SRL is learning process influenced by thinking, feeling, strategy, and own behaviour that oriented to a realizing goal, and it involves three phases namely: to design learning, to observe learning activities, and to assess and to reflect learning out comes (Schunk and Zimmerman, 1998); d. SRL is self-regulation in designing, implementing, and assessing their own learning

Some authors propose suggestion for improving SRL among other as follow: a. Help student to excecute the cycle of SRL flexibly and adaptively (Butler, 2002, as cited in Sumarmo, 2006, 2011); b. Make student realize on the meaning and the importance of having SRL; Perform teacher and familiarize students to behave as expected in SRL; Carry out integrated and continous mathematics teaching-learning process (Sauri, 2010).

\section{Child's Cognitive Development}

To overcome time consuming for implementing depth observation and interview for a number of students in shorter time at once, Tobin and Capie (1981, as cited in Sumarmo, 2019) developed a written tes called test of logical thinking (TOLT), and McDonald \& Sheehan, (1983). consrructed Longeot test, and both of tests were compiled based on theory of Inhelder and Piaget"s theory of child cognitive develpoment. Capie and Tobin (1980, 1981 as cite in Sumarmo, 2019) by using TOLT and Longeot test, found many subjects of more than 15 years old had not attained formal operational stage yet. Then, Sumarmo (1987, as cited in Sumarmo, 2019) carried out a deep survey with 414 eleventh grade students by using TOLT and Longeot test to measure student's cognitive stage. As well as, she found many students of more than 17.43 years old hadn't reached formal stage yet, and only $48 \%$ students were at formal operational stage (Sumarmo, 1987 as cited in Sumarmo, 2019). That finding was different with Piaget's theory (1972, as cited in Sumarmo, 2019) but it was not contradiction to Inhelder and Peiaget's Theory that normal subject will reach formal operational stage in between 11- 12 years old up to $14-15$ years old, even in other condition in $18-20$ years old.

\section{Inquiry Approach}

Gulo (2002) elaborates five components of IA approach more detailed: a. Question: At the start of the lesson teacher presents an open problem which motivate students to ask, and then teacher asking main question of the problem; b. Student Engangement: in this approach students are motivated to create an idea about concepts that is being studied; c. Cooperative Interaction : Students work in small group to discuss teacher's open question with many posible right answers; d. Performance Evaluation: Usually, student's answers can be a graph, a poster, an essay, or other form. Through those student's answer then teacher assess student's understanding of the problem. Then, Trianto (2007) put forward some phases of inquiry approach, such as: To pose question or problem, to formulate hypothses, to design experiment, to collect data, to analyze data, an to derive conclussion.

\section{Relevant Research}

Apart from the study findings that have been reported, other studies (Offirston. \& Sumarmo, 2012, and Supiyanto, Hendriana, Maya, 2018) by implementing IA found that students obtained at medium grade level on matematical reasoning and mathematical strategic competence and disposition. 
78 Sukarna, N., Sumarmo, U., \& Kurniawan, $R$, The Role of Inquiry Approach and Cognitive

Stage on Student's Mathematical Critical Thinking Ability and Self Regulated Learning

As well as, some studies (Sumarni, \& Sumarmo, 2017, Mulyana, Sumarmo, Kurniawan, 2018) reported that students getting treatment with variety of teaching approaches obtained MCTA at medium grade level. Nonetheless, other studies (Mulyana \& Hendriana, 2015, Rohaeti, Budiyanto, Sumarmo, 2014, Krisnawati, Rohaeti. Maya, 2018, Sumarni, \& Sumarmo, 2017, Sopian, \& Sabandar, 2018) by implementing variety of inovative teaching approaches reported that students attained at fairly good grade on MSRL.

Related to the cognitive stage of students, Gunawan, Prawoto, Sumarmo, (2019), Saepul, Puspowati, Sumarmo (2019), and Sumarmo (1987, as cited in Sumarmo 2019) reported their findings as follow: the percentage of formal students of those studies successively were $25 \%$ (out of $36 \mathrm{Ss}$ ), $36 \%$ (out of $36 \mathrm{Ss}$ ), and $48 \%$ (ouf $414 \mathrm{Ss}$ ).

\section{METHOD}

This research was a pretest-postest experimental control group design having a goal to analyze the role of Inquiry approach (IA) and Cognitive Stage (CS) on students' MCTA and MSRL. The research involved 30 eleventh grade students, a MCTA test, and a MSRL scale, and TOLT the Longeot test. Before we used the instruments, researchers consulted the instruments to two mathematics education experts for getting a dicission that the instruments have sufficient content validity degree. Then by using Hendriana and Sumarmo (2014) and Sumarmo (2015) as references, researchers obtained charactristic MCTA test, TOLT, the Longeot tes, and MSRL scale as attached in Table 1.

Table 1. Characteristis MCTA test and MSRL Scale

\begin{tabular}{llllllll}
\hline $\begin{array}{l}\text { Instrument } \\
\mathrm{s}\end{array}$ & $\begin{array}{l}\mathrm{n} \text { of } \\
\text { subjec } \\
\mathrm{t}\end{array}$ & $\begin{array}{l}\mathrm{n} \text { instrume } \\
\mathrm{nt}\end{array}$ & $\begin{array}{l}\text { Reliabilit } \\
\mathrm{y}\end{array}$ & $\begin{array}{l}\text { Item } \\
\text { Validity }\end{array}$ & $\begin{array}{l}\text { Difficult } \\
\mathrm{y} \\
\text { Index }\end{array}$ & $\begin{array}{l}\text { Discrimin } \\
\text { at Power }\end{array}$ & $\begin{array}{l}\mathrm{t}_{\text {calculation }} \\
(\mathrm{t} \text { table } \\
1.31)\end{array}$ \\
\hline MRA test & 28 & 5 & .72 & $.40-.83$ & $.12-.67$ & $.19-.89$ & - \\
\hline $\begin{array}{l}\text { MSRL } \\
\text { scale }\end{array}$ & 28 & 34 & .83 & - & - & - & 0.0 \\
\hline TOLT $*)$ & 92 & 10 & .66 & $.42-.84$ & $.37-.83$ & $.59-.81$ & - \\
\hline $\begin{array}{l}\text { Longeot } \\
\text { test } *)\end{array}$ & 92 & 26 & .68 & $.00-.54$ & $\begin{array}{l}.02 \\
1.00\end{array}$ & $.00-.87$ & - \\
\hline
\end{tabular}

Note: *) from Sumarmo, 2019

In the following we attached some sample of instruments of this study.

Sampel 1: Solving a problem of derivative function and to draw its graph accompanied with relevant reason.

It is given $\mathrm{f}(\mathrm{x})=x^{2}-3 x-4$ and $l \equiv 3 x-\mathrm{y}=6$

a. Determine equation of tangent $\mathrm{k}$ toward $\mathrm{f}(\mathrm{x})$ paralel to the line 1 .

b. Determine interval when function $\mathrm{f}(\mathrm{x})$ is ride, is down and some important points;

c. Determine extreme value and its type of $f(x)$

d. Draw the skecth of $\mathrm{f}(\mathrm{x})$ and the tangent of $\mathrm{k}$. Write reason, concept, or rules used in each step of the calculation.

Sample 2. Combination reasoning of Longeot test

The Dance: After a family meal, it is decided to go dancing.

There are three boys: Albert, Bob, Charles

and there girls: Louise, Mary, Nancy 
What are all the possible couples (boys with girls) of dancer? Write then on the lines, indicating the first letter of the name of dancer. One couple is already written on yhe first line:

A L, which means ALBERT and LOUISE. Write the others, using one pair of lines for each of the couples of dancers.

Remenber: It is not necessary to use all the lines.

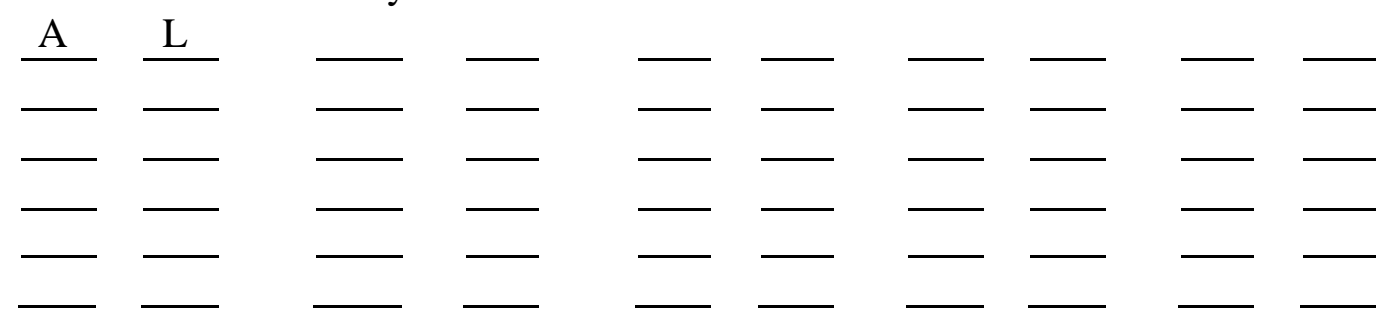

Sample 3: item of TOLT (The Pendulum's Length)

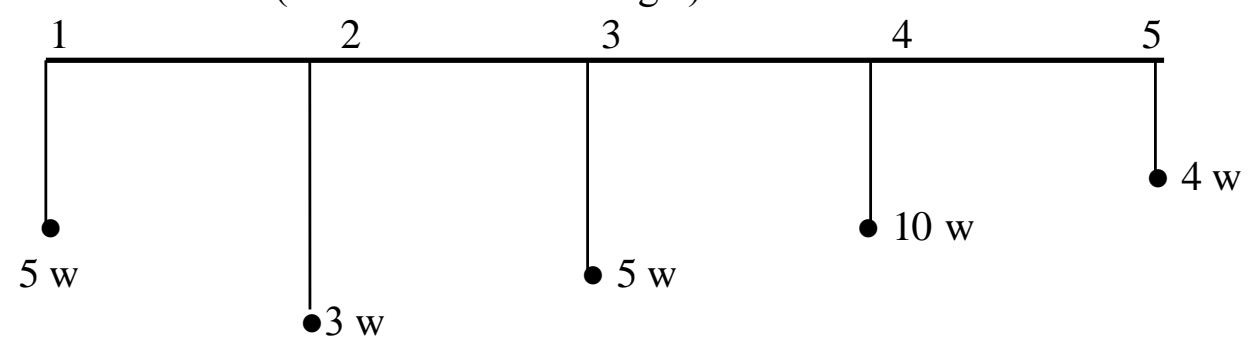

Suppose you wanted to do an experiment to find out if changing the length of a pendulum changed the amount of time it takes to swing back and forth. Which of the pendulum would you use for the experiment?
a. 1 and 4
b. 2 and 4
c. 1 and 3
d. 2 and 5
e. All

Reasons:

1. The longest pendulum should be tested against the shortest pendulum.

2. All pendulum need to be tested against one another.

3. As the length is increased the number of washers should be decreased.

4. The pendulum should be the same length but the number of washers sould be different.

5. The pendulums should be different lengths but the number of washers should be the same.

Sample 4. Some statements of Self Regulated Learning

\begin{tabular}{l} 
No. Statements \\
\hline 1. I learn algebraic derivative function and its \\
application caused of I like it. \\
2. I am confused to determine which topic should be \\
re-studied \\
3. I think determination of target value in future \\
derivative function test will prevent me from \\
learning \\
4. I avoid to summerize about application of derivative \\
function in daily life problem from some books.
\end{tabular}


80 Sukarna, N., Sumarmo, U., \& Kurniawan, $R$, The Role of Inquiry Approach and Cognitive Stage on Student's Mathematical Critical Thinking Ability and Self Regulated Learning

\begin{tabular}{l} 
No. Statements \\
\hline 5. I summerize traits and formulas of derivative \\
function for strethening my understanding.
\end{tabular}

8. I try to examine the truth of work about graph of a function though it need a long time.

Note: SA : strongly agree; A :agree;

DA : disagree; SDA : strongly disagree

\section{RESULT AND DISCUSSIONS}

By using the TOLT and Longeot test, we found percentages of students classified by TOLT and longeot were attached in Tabel 2. In further analysis, we named a student at concrete CS or at formal CS when he or she was at concrete CS or formal CS in both TOLT and Longeot test.

Table 2. Percentage of Students in Each Cognitive Stage Measured by TOLT and Longeot

\begin{tabular}{|c|c|c|c|c|c|c|c|}
\hline \multirow{3}{*}{ Instrument } & \multirow{3}{*}{$\begin{array}{l}n \text { of } \\
\text { subject }\end{array}$} & \multicolumn{4}{|c|}{ Test } & \multirow{2}{*}{\multicolumn{2}{|c|}{ Formal Operational }} \\
\hline & & $\begin{array}{l}\mathrm{Co} \\
\mathrm{Op}\end{array}$ & & $\begin{array}{l}\text { Tra } \\
\text { Op }\end{array}$ & & & \\
\hline & & $\mathrm{n}$ & $\%$ & $\mathrm{n}$ & $\%$ & $\mathrm{n}$ & $\%$ \\
\hline TOLT & 60 & 31 & 51.7 & 15 & 25.0 & 14 & 23.3 \\
\hline Longeot test & 60 & 8 & 13.3 & 0 & .00 & 52 & 86.7 \\
\hline Overall & 60 & 7 & 11.7 & 39 & 65.0 & 14 & 23.3 \\
\hline
\end{tabular}

In the pretest, either overall students or based on their cognitive stage, there were no different grades of students' MCTA and students' MSRL. This findings were rational caused of students have not yet learned the mathematical content will be studied. After learning is over, for overall students, on MCTA students getting treatment with IA obtained higher grade than the grade of students taught by SA, the first group reached at fairly good grade level while the second group obtain at medium grade level. However, after learning process on MSRL there was no different grades among students of the both classess, and those grades were at fairly good grade level.

Further findings of this study were the attaiment of student's MCTA and its gain $(<\mathrm{N}-\mathrm{G}\rangle$ MCTA), and student's MSRL as attached in Table 3.

Table 3. Student's MCTA and Its Gain (N-G), and Student's MSRL Based Cognitve Stage In Both Teaching Approaches

\begin{tabular}{|c|c|c|c|c|c|c|c|c|c|c|}
\hline \multirow[b]{2}{*}{$\begin{array}{l}\text { Variable } \\
\mathrm{s}\end{array}$} & \multirow[b]{2}{*}{ CS } & \multirow{2}{*}{$\begin{array}{l}\text { Stat. } \\
\text { Des } \\
\text { c. } \\
\end{array}$} & \multicolumn{4}{|c|}{ Inquiry Approach (IA) } & \multicolumn{4}{|c|}{ Saintific Approach (SA) } \\
\hline & & & Pretes & Post & $\langle g\rangle$ & $\mathrm{n}$ & Prete & Postes & $\langle g\rangle$ & $\mathrm{n}$ \\
\hline & & $\bar{x}$ & 3.33 & 38.22 & \multirow{2}{*}{.60} & \multirow{3}{*}{9} & 2.80 & 31.20 & \multirow{2}{*}{.49} & \multirow{3}{*}{5} \\
\hline & \multirow{2}{*}{$\begin{array}{l}\text { For. } \\
\text { CS }\end{array}$} & $(\%)$ & 5.46 & 62.66 & & & 4.59 & 51.15 & & \\
\hline & & $\mathrm{S}$ & 2.24 & 9.27 & .16 & & 2.28 & 13.16 & .22 & \\
\hline & & $\bar{x}$ & 3.95 & 38.89 & \multirow{2}{*}{61} & \multirow{2}{*}{19} & 3.35 & 22.25 & \multirow{2}{*}{.33} & \multirow{2}{*}{20} \\
\hline & $\operatorname{Tr}$ & $(\%)$ & 6.47 & 63.76 & & & 5.49 & 36.48 & & \\
\hline
\end{tabular}




\begin{tabular}{|c|c|c|c|c|c|c|c|c|c|c|}
\hline \multirow[b]{2}{*}{$\begin{array}{l}\text { Variable } \\
\text { s }\end{array}$} & \multirow{2}{*}{ CS } & \multirow{2}{*}{$\begin{array}{l}\text { Stat. } \\
\text { Des } \\
\text { c. }\end{array}$} & \multicolumn{3}{|c|}{ Inquiry Approach (IA) } & \multicolumn{5}{|c|}{ Saintific Approach (SA) } \\
\hline & & & Pretes & Post & $\langle g\rangle$ & $\mathrm{n}$ & Prete & Postes & $\langle g\rangle$ & $\mathrm{n}$ \\
\hline \multirow{7}{*}{ MCTA } & $\mathrm{CS}$ & $\mathrm{S}$ & 2.46 & 8.61 & .15 & & 2.58 & 11.22 & .15 & \\
\hline & \multirow{3}{*}{$\begin{array}{l}\mathrm{Cr} \\
\mathrm{CS} \\
\end{array}$} & $\bar{x}$ & 2.00 & 33.00 & \multirow[t]{2}{*}{.53} & \multirow{3}{*}{2} & 1.40 & 20.80 & \multirow{2}{*}{.33} & \multirow{3}{*}{5} \\
\hline & & $(\%)$ & 3.28 & 54.10 & & & 2.30 & 34.10 & & \\
\hline & & $\mathrm{s}$ & 2.83 & 7.07 & .10 & & 0.89 & 9.52 &, 18 & \\
\hline & \multirow{3}{*}{$\begin{array}{l}\text { Ove } \\
\text { rall }\end{array}$} & $\bar{x}$ & 3.63 & 38.30 & \multirow{2}{*}{.60} & \multirow{3}{*}{30} & 2.93 & 23.50 & & \multirow{3}{*}{30} \\
\hline & & $(\%)$ & 5.96 & 62.79 & & & 4.81 & 38.52 & .36 & \\
\hline & & $\mathrm{s}$ & 2.39 & 8.58 & .15 & & 2.39 & 11.47 & .19 & \\
\hline \multirow{12}{*}{ MSRL } & \multirow{3}{*}{$\begin{array}{l}\text { For. } \\
\text { CS }\end{array}$} & $\overline{\bar{x}}$ & & 82.33 & & \multirow{3}{*}{9} & & 99.00 & & \multirow{3}{*}{5} \\
\hline & & $(\%)$ & & 58.39 & & & & 70.21 & & \\
\hline & & $\mathrm{s}$ & & 11.09 & & & & 12.45 & & \\
\hline & \multirow{4}{*}{$\begin{array}{l}\mathrm{Tr} \\
\mathrm{CS} \\
\end{array}$} & $\bar{x}$ & & 88.42 & & \multirow{3}{*}{19} & & 90.55 & & \multirow{3}{*}{20} \\
\hline & & $(\%)$ & & 62.71 & & & & 64.21 & & \\
\hline & & $\mathrm{s}$ & & 15.69 & & & & 10.00 & & \\
\hline & & $\bar{x}$ & & 110.50 & & \multirow{3}{*}{2} & & 89.80 & & \multirow{3}{*}{5} \\
\hline & \multirow{2}{*}{$\begin{array}{l}\mathrm{Cr} \\
\mathrm{CS}\end{array}$} & (\%) & & 78.37 & & & & 63.69 & & \\
\hline & & $\mathrm{s}$ & & 43.13 & & & & 9.04 & & \\
\hline & \multirow{3}{*}{$\begin{array}{l}\text { Ove } \\
\text { rall }\end{array}$} & $\bar{x}$ & & 88.07 & & \multirow{3}{*}{30} & & 91.83 & & \multirow{3}{*}{30} \\
\hline & & (\%) & & 62.46 & & & & 65.13 & & \\
\hline & & $\mathrm{s}$ & & 17.20 & & & & 10.44 & & \\
\hline
\end{tabular}

\section{Note:}

MCTA : mathematical critical thinking ability, Ideal Score: 61 MSRL : mathematical self regulated learning,

Reviewed based on students' cognitive stages, in both classess, on MCTA formal and transition stage students obtained higher grade than the grade of concrete stage students. Those fingdings pointed out that IA and CS took big role on improving students' MCTA and its gain. But the role of IA didn't occur with MSRL. There were no different grade of MSRL among the cognitive stages of students.

Table 4. Testing Hypotesis of Mean Difference of Mathematical Critial Thinking Ability It's N-Gain, and Self Regulated Learning for Overall Students

\begin{tabular}{|c|c|c|c|c|c|c|}
\hline Variable & $\begin{array}{l}\text { Teaching } \\
\text { approach }\end{array}$ & $\bar{x}$ & SD & $\mathrm{n}$ & Sig. & Interpretation \\
\hline \multirow{2}{*}{ MCTA } & IA & 38.30 & 8.58 & 30 & \multirow{2}{*}{$.001<.05$} & \multirow{2}{*}{ MCTA $_{\text {IA }}>$ MCTA $_{\mathrm{SA}}$} \\
\hline & $\mathrm{SA}$ & 23.50 & 11.47 & 30 & & \\
\hline \multirow{2}{*}{$\begin{array}{l}\text { N-Gain of } \\
\text { MCTA }\end{array}$} & IA & .60 & .15 & 30 & \multirow{2}{*}{$\begin{array}{l}.002 \\
.05\end{array}$} & \multirow{2}{*}{$\begin{array}{l}\text { N-Gain MCTA }_{\text {IA }}> \\
\text { N-Gain MCTA }_{S A}\end{array}$} \\
\hline & SA & .36 & .19 & 30 & & \\
\hline \multirow{2}{*}{ MSRL } & IA & 88.07 & 17.20 & 30 & \multirow{2}{*}{$.896<.05$} & \multirow{2}{*}{$\operatorname{MSRL}_{\mathrm{IA}}=\operatorname{MSRL}_{\mathrm{SA}}$} \\
\hline & SA & 91.83 & 10.44 & 30 & & \\
\hline
\end{tabular}

Note: MCTA : mathematical critical thinking ability Ideal score MCTA: 61

MSRL : mathematical self regulation learning Ideal scor of MSRL : 141

In this study, IA and CS took bigger role than SA on student's MCTA, and its $\mathrm{N}<\mathrm{G}>$, but not on student's MSRL. Those findings were similar to findings of recent studies (Mulyana, Sumarmo, \& Kurniawan, 2018, Sumarni \& Sumarmo, 2017) that students getting treatment 
Stage on Student's Mathematical Critical Thinking Ability and Self Regulated Learning

with variety of teaching approaches obtained higher grade on MCTA and some studies (Mulyana \& Hendriana, 2015, Rohaeti, Budiyanto, Sumarmo, 2014, Krisnawati, Rohaeti. Maya, 2018, Sumarni, \& Sumarmo, 2017, Sopian \& Sabandar, 2018) on MSRL than the grades of students taught by SA.

Table 5. Mean Score Of Each Item Of Mathematical Critical Thinking Ability Test of Students In Both Teaching Approaches

\begin{tabular}{|c|c|c|c|c|c|c|c|}
\hline \multirow{2}{*}{$\begin{array}{l}\text { Teaching } \\
\text { approach }\end{array}$} & \multirow{2}{*}{$\mathrm{CS}$} & Stat.Desc & No.1 & No 2. & No.3 & No.4 & No.5 \\
\hline & & Ideal score & 12 & 15 & 10 & 12 & 12 \\
\hline \multirow{8}{*}{ IA } & \multirow{2}{*}{$\mathrm{F}$} & $\bar{x}$ & 9,33 & 8,22 & 7,44 & 7,11 & 6,11 \\
\hline & & $\%$ out of IS & 77,78 & 54,81 & 74,44 & 59,26 & 50.93 \\
\hline & \multirow{2}{*}{$\mathrm{T}$} & $\bar{x}$ & 9.42 & 8.58 & 7.32 & 7.00 & 6.58 \\
\hline & & $\%$ out of IS & 78.51 & 57.19 & 73.16 & 58.33 & 54.82 \\
\hline & \multirow{2}{*}{$\mathrm{C}$} & $\overline{\bar{x}}$ & 8.00 & 8.00 & 6.00 & 6.00 & 5.00 \\
\hline & & $\%$ out of IS & 66.67 & 53.33 & 60.00 & 50.00 & 41.67 \\
\hline & \multirow{2}{*}{ All } & $\bar{x}$ & 9.30 & 8.43 & 7.27 & 6.97 & 6.33 \\
\hline & & $\%$ out of IS & 77.50 & 56.22 & 72.67 & 58.06 & 52.78 \\
\hline \multirow{8}{*}{ SA } & \multirow{2}{*}{$\mathrm{F}$} & $\bar{x}$ & 8.80 & 9.60 & 4.20 & 2.60 & 6.00 \\
\hline & & $\%$ out of IS & 73.33 & 64.00 & 42.00 & 21.67 & 50.00 \\
\hline & \multirow{2}{*}{$\mathrm{T}$} & $\bar{x}$ & 6.70 & 6.75 & 2.45 & 2.25 & 4.10 \\
\hline & & $\%$ out of IS & 55.83 & 45.00 & 24.50 & 18.75 & 34.17 \\
\hline & \multirow{2}{*}{$\mathrm{C}$} & $\bar{x}$ & 5.80 & 6.60 & 1.60 & 1.60 & 5.20 \\
\hline & & $\%$ out of IS & 48.33 & 44.00 & 16.00 & 13.33 & 43.33 \\
\hline & \multirow{2}{*}{ All } & $\bar{x}$ & 6.90 & 7.20 & 2.60 & 2.20 & 4.60 \\
\hline & & $\%$ out of IS & 57.50 & 48.00 & 26.00 & 18.33 & 38.33 \\
\hline
\end{tabular}

Next analysis was about students' difficulties on solving MCTA tasks, and the findings were attached on Tabel 5. The study found that students getting treatment with IA realized less difficulties on solving MCTA tasks compere to students taught by SA. Based on CS of students on both teaching approaches, concrete students met more difficulties on solving MCTA than transitional and formal cognitive stages.

In further analysis, by using contigency table between MCTS and CS, between MCTA and MSRL and between CS and MSRL, (and using statistic Pearson-Chi Square $\left(\chi^{2}\right)$ and data analysis using SPSS for window, the study found value of $\chi^{2}$ and C coefficient and Q coefficient as in Table 6.

Table 6. Test of Pearson-Chi Square MCTA and CS, MCTA and MSRL, and CS and MSRL

\begin{tabular}{lllll}
\hline $\begin{array}{l}\text { Testing of } \\
\text { association between }\end{array}$ & $\begin{array}{l}\text { Pearson- } \\
\text { Chi Square } \\
\left(\chi^{2}\right)\end{array}$ & DF & Sig.(2-tailed) & Interpretation \\
\hline MCTA - CS & $1.781^{\mathrm{a}}$ & 4 & $.776>.05$ & no association \\
MCTA - MSRL & $2.741^{\mathrm{a}}$ & 4 & $.602>.05$ & no association \\
CS - MSRL & $3.979^{\mathrm{a}}$ & 4 & $.409>.05$ & no association \\
\hline
\end{tabular}

Based on the calculation results listed in Table 6, the study obtained the following meaning:

a. There was no association between MCTA and CS

b. There was no association between MCTA and MSRL 
c. There was no association between CS and MSRL

Those findings was different to findings of Prihatini, Hidayat, \& Rohaeti (2019) and Hidayat, Akbar, \& Bernard (2018) that there was association between MCTA and SRL. (Aminah, et.all, 2012, Mulyana, \& Hendriana, 2015, Rohaeti, et.all., 2014), and between CS and mathematical reasoning (Gunawan, et.all. 2019) and between CS and mathematical creative thinking ability MCTA) (Saepul et.all, 2019). However, those findings were different with finding of other study that there were no, between CS and SRL (Gunawan, et.all., 2019) and between CS and HoM. Those findings pointed out that there were inconsistent existency of association between mathematical hard-skills and soft-skills.

Further analysis was about students activities during IA lessons and SA lessons. Students performed good performance and participated the lessons, such as they work together to identify the problem actively (Figure 1), one of the groups presented the results of the answer in front of the class (Figure 2).

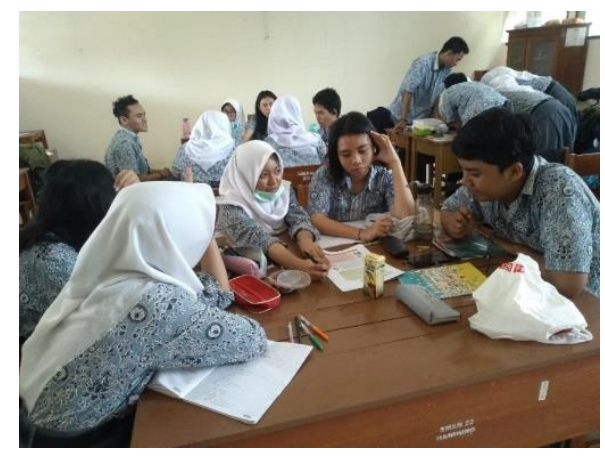

Figure 1. Students identify Problemon their work sheet actively

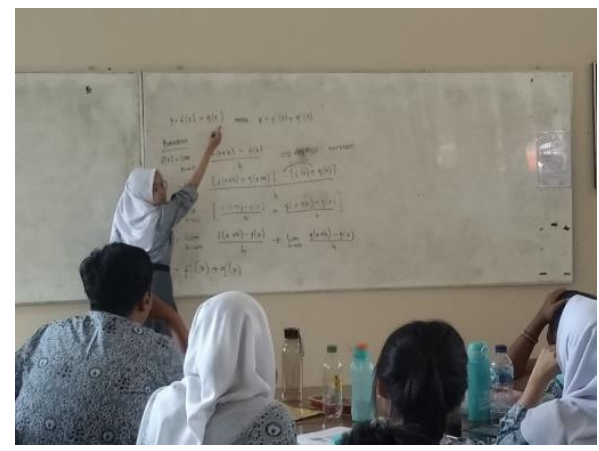

Figure 2. One of the groups presented the results of the answer in front of

Moreover, students tended to be comfortable with the new accepted teaching approach (IA) despite at first they were confused to solve new kind mathematics problems. In this study, sometimes teacher faced obstacles in conducting IA, such as limitted allocated time whereas IA needed more time for students to construct their knowledge, to discuss in their group, and to derive conclussion. Eventhough, in further sesions the obstacles could be handled by offering more interesting mathematics task and guidance during students working together in each small group.

\section{CONCLUSION}

Based on study findings and discussion, the study derived some conclussion as follow. Inquiry approach (IA) and Cognitive Stage (CS) took bigger role than the role of SA on improving students' mathematical critical thinking ablity (MCTA) and its gain. Students getting treatment with IA obtained MCTA at fairly good grade level, while students taught by saintific approach (SA) attained at medium grade level. Reviewed based on cognitive stages, in both learning classes (IA and SA) on MCTA, formal stage students attained better grade than the grade of transition stage students and the grade of concrete stage students. The implication of the findings is that the concrete stage students experience more difficulties than the difficulties of the transition stage students and the difficulty of the concrete stage student.

But in MSRL, there was no different grade of MSRL of students in both learning, and those grades were at fairly grade level. Likewise, there was no difference in the grade of MSRL 
84 Sukarna, N., Sumarmo, U., \& Kurniawan, $R$, The Role of Inquiry Approach and Cognitive

Stage on Student's Mathematical Critical Thinking Ability and Self Regulated Learning

among formal stage, transsition, and concrete stage students. Another conclusion is that there is no association between MCTA and MSRL, MCTA and CS, and between CS and MSRL. With regard to students' opinions on IA learning, students show a pleasure to learn in groups, choose their own practice questions, and want to present their work in front of the class voluntarily.

In order students to master MCTA better, students should more practice on checking the truth of each calculation step, and proving the truth of a statement. Then, for improving student's MSRL students should to demonstrate self regulated learning as a habit, and teacher should carry out comprehensive and continuous teaching-learning mathematics.

\section{REFERENCES}

Aminah, M., Kusumah, Y.S., Suryadi, D., and Sumarmo,U. (2018). "The Effect of Metacognitive Teaching and Mathematical Prior Knowledge on Mathematical Logic al Thinking Ability and Self-Regulated Learning". Paper published in International Journal of Instruction. July, 2018. Vol. 11-number.3.

Baron, J. B. dan Sternberg, R.J. (Editor), (1987) Teaching Thinking Skill. New York: W.H. Freeman and Company

Butler, D.L. (2002). Individualizing Instrction in Self-Regulated Learning. $\mathrm{http} / /$ articles.findarticles.com/p/articles/mimOQM/is_2_41/ni_90190495

Damayanti, D.T., Sumarmo. S., Maya, R. (2018). "Improving Student's Mathematical Creative Thinking Ability and Self Regulated Learning using Sylver Approach". JPMI. Volume 1 Number 3, September 2018, pp. 268-278

Fisher, A. (2009). Berpikir Kritis: Sebuah Pengantar. Jakarta: Erlangga.Garton, (2005

Gokhale, A. A. (1995). Collaborative Learning Enhances Critical Thinking. [Online]. Tersedia: http://Scholer.lib.vt.edu./e journals/JTEI V7 n1/pdf/Gokhale.pdf.

Glazer, E. (2004). Technology Enhanced Learning Environment that are Conductive of Critical Thinking in Mathematics.[online]. Tersedia: http://www.lonestar.texas.net/scifert/crit2.html 6 Desember 2009.

Gulo. (2002). Strategi Belajar-Mengajar. Jakarta: Grasindo.

Gunawan, Prawoto, A., Sumarmo, U. (2019). "Mathematical Reasoning And Self Regulated Learning According to Student's Cognitive Stage”. JPMI Volume 2,No.1 . 2019. Hal. $39-52)$

Hargis, J dan Kerlin, B. A.(1992). Cognitive Engagemant Style: Self-Regulated Learning and Cooperative Learning. Science on the Internet.

Hassoubah, I, Z. (2007). Mengasah Pikiran Kreatif dan Kritis Disertai Ilustrasi dan Latihan. Bandung : Nuansa

Hendriana, H \& Sumarmo, U (2014).Penilaian Pembelajaran Matematika. Bandung: Penerbit PT Refika Aditama. Bandung.

Hendriana, Rohaeti, Sumarmo, 2017 Hard Skill dan Soft Skill Mathematika.Bandung: Penerbit PT Refika Aditama. Bandung.

Inhelder, B \& Piaget, J. (1972). The Growth of Logical Thikning from Cildhood to Adolescence. (Cetakan Keempat). Routlege and Kegan Paul Ltd. London.

Johnson, E. (2007). Contextual Teaching and Learning : Menjadikan Kegiatan BelajarMengajar Mengasyikan dan Bermakna. Bandung : MLC

Kurniawati, L., Kusumah, Y.S., Sumarmo, U. Sabandar, Y. (2014). Enhancing Students' mathematical intuitive-reflective thinking ability through problem based learning with hypnoteaching method. Paper published in Journal of Education and Practice, Vol.(6) No.36, 2014 pp 130-135. ISSN 2222-1736 (paper). Available online: http//www.iist. org/journal/index.php/JEP/articel/view/17480, ISSN 2222-288x (on line) 
Krisnawati, R., Rohaeti, E.E., Maya, R. (2018). Application Of A Realistic Approach To Improve The Ability Of Mathematical Problem Solving And Self Regulated Learning Of Junior High School Students. JPMI. Volume 1 Number 2, June 2018, pp

Lestari, K.E. (2013). Implementasi BRAIN-BASED LEARNING untuk Meningkatkan Kemampuan Koneksi dan kemampuan berpikir kritis Matematis Siswa Sekolah Menengah Pertama. (Online) Tersedia : repository.upi.edu/609/. (19 Maret 2016)

Lunenburg, F.C. (2011). "Critical Thinking and Constructivism Techniques for Improving Student Achievement". Paper published in National Forum Teacher Education Journal.21,(3), 1-9 .

McDonald, J.L. \& Sheehan, D. J. (1983). Use of The Longeot Test to Assess Formal Operations: A Research Summary . Paper presented as Part of Symposium on The Assessment of Formal Operation within Diverse Samples and Diverse Instrument, at The Thirteenth Annual Symposium of the Jean Piaget Society, Philadelphia, June 1983.

Mulyana, A. Sumarmo, U., Kurniawan, R. (2018). "The Role of Problem Solving Approach on Student's Mathematical Critical Thinking Ability and Disposition:” JPMI

Volume 1 Number 3, September 2018, pp.256-267

Mulyana, A \& Hendriana, H. (2015). "Meningkatkan Kemampuan Penalaran Matematik dan Kemandirian Belajar Siswa SMP melalui Pembelajaran Berbasis Masalah". Paper published in Edusentris, Jurnal Ilmu Pendidikan dan Pengajaran, Vol. 2, No. July 2015.

Murni, S. Sugandi., A.I. (2018). "The Role Of Mathematics Realistic Education Approach On Students' Mathematical Critical Thinking And Resiliency”. Infinity. Volume 1 Number 1, March 2018, pp. 41-52

NCTM. (2000). Principles and Standards for School Mathematics. Reston. VA: NCTM.

Nurfalah, A., Prihatini, D., Hidayat, W. \& Rohaeti, E.E. (2019). Hubungan Antara Kemampuan Berpikir Kritis Matematis Dan Kemandirian Belajar Siswa SMA Cimahi. Journal On Education 02 (01): 167-73.

Nurina, H. (2014). "Keefektifan PBL Ditinjau Dari Kemampuan Berpikir Kritis dan Kreatif Matematis serta Self Esteem Siswa SMP”. Paper published in Jurnal Riset Pendidikan Matematika, Volume 01, Nomor 01.

Offirston. T. and Sumarmo, U. (2012). "Pendekatan Inkuiri Berbantuan Software Cinderella untuk Meningkatkan Kemampuan Penalaran dan Pemecahan Masalah Matematis Siswa MTs". Paper published in: Educationist: Jurnal kajian filosofi, teori, kualitas, dan manajemen pendidikanVol VI. No.2, 101-106, July 2012.

Palinussa, A. L. (2013). "Students' critical Mathematical Thinking Skills and Character. " Experiment for Yunior High School Students through Realistic Mathematics Education Culture Based. Paper published in: IndoMS Journal on Mathematics Education (IndoMSJME), Vol. 4, No. 1. January 2013, pp. 75-94.

Peraturan Menteri Pendidikan Nasional No. 81a Tahun 2013 tanggal 27 Juni 2013 tentang Implementasi Kurikulum Standar Isi.

Peter, A. (2010). Critical Thinking: What It Is and Why It Counts. [Online] Tersedia: http://www.telacommunications.com/nutshell/cthinking.htmIDiakses: 8 Januari 2011.

Peter, E.E. (2012). "Critical Thinking: Essence for Teaching Mathematics and Mathematics Problem Solving Skills". African Journal of Mathematics and Computer Science Research. 5, (93), pp 39-43.

Polya, G. (1975). How to Solve It. A New Aspect of Mathematical Method. New Jersey: Princenton University Press.

Retnaningsih, M., Sugandi, A.I. (2018). "The Role of Problem Based Learning on Improving Students' Mathematical Critical Thinking Ability and Self-Regulated Learning." JPMI Volume 1 Number 2, June 2018, pp. 60-69 
Stage on Student's Mathematical Critical Thinking Ability and Self Regulated Learning

Krisnawati, R., Rohaeti. E.E., Maya, R. (2018). “Application Of A Realistic Approach To Improve The Ability of Mathematical Problem Solving And Self Regulated Learning of Junior High School Students". JPMI. Volume 1 Number 2, June 2018, pp. 179-185

Rohaeti, E.E. Budiyanto, A.M., Sumarmo, U (2014). "Enhancing Mathematical Logical Thinking Ability and Self Regulated Learning of Students through Problem Based Learning". Paper published in International Journal of Education Vol.8, No. 1. Desember 2014. pp 54-63. Graduate School, Indonesia University of Education.

Romlah, Sumarmo, U. Syaban, M. (2018). "Mathematical Problem Solving Ability and Self Regulated Learning: Experiment With Eighth Grade Student Using Metacognitive Approach". Jurnal Nasional Pendidikan Matematika (JNPM) (on line Euclid Vol.3 No 1. Edisi Maret 2019. http://jurnal. unswagati.ac.id/index,php/JNPM

Saepul I.R., Puspowati, A.K., Utari Sumarmo, U. (2019).” Mathematical Creative Thinking And Habits Of Mind Grounded On Student's Cognitive Stage”. JPMI Vol. 1. No.4. 2019. Hal. 374-382.

Sauri, S. (2010). Membangun Karakter Bangsa melalui Pembinaan Profesionalisme Guru Berbasis Pendidikan Nilai. Jurnal Pendidikan Karakter. Vol.2. No.2.

Schunck, D.H., \& Zimmerman, B.J.(1998). Introduction to the Self Regulated Learning (SRL) Cycle.

Sumarni, C. and Sumarmo, U. (2017). Penalaran Matematik dan Kemandirian Belajar: Eksperimen terhadap Siswa SMP melalui Pembelajaran Generatif. Paper published in Edusentris: Jurnal Ilmu Pendidikan dan Pengajaran.Vol.3. No.1. April. 2017, pp. 290299.

Sumarmo, U. (2006). "Kemandirian belajar: Apa, mengapa dan bagaimana dikembangkan pada peserta didik" Paper presented at Seminar of Mathematics Education in Department of Mathematics, Faculty of Mathematics and Science, State University of Yogyakarta. Paper published in Suryadi, D, Turmudi, Nurlaelah, E. (Editors). Kumpulan Makalah Proses Berpikir dan Disposisi Matematik dan Pembelajarannya. 2014. Mathematics Deparment of Faculty Mathematics and Science Education UPI. Bandung. pp. 109-122

Sumarmo, U. (2015). Rubrik Pemberian Skor Tes Kemampuan Matematika. Tersedia: http/www.utari-sumarmo.dosen.stkipsiliwangi.ac.id [30 Juli2016]

Sopian, A., \& Sabandar, Y. (2018). Improving The Ability Of Mathematic Problem Solving, Mathematic Connection And Self Regulated Learning With Junior High School Students Through Metakognitive Approach. JPMI. Volume 1 Number 2, June 2018, pp. 116-122

Supiyanto, Hendriana, H. Maya, R.. (2018). Improving the Capabilities of Strategic Competence and Mathematical Disposition Using the Inquiri Model of Alberta Method". JPMI, Volume 1 Number 3, September 2018, pp 225-232.Prestasi Pustaka

Tobin, K.G \& Capie, . (1981). Developmental Patterns Among Formal Reasoning Skill. A Paper presented at The Eleven Annual Symposium of The Jean Piaget Society, Philadelpia, Pensylvania.

Trianto. (2009). Mendesain Model Pembelajaran Inovatif-Progresif: Konsep, Landasan, dan Implementasinya pada Kurikulum Tingkat Satuan Pendidikan (KTSP). Jakarta: Kencana

Wardani, S., Sumarmo,U., Izumi NISHITANI, (2011). "Mathematical Creativity and Disposition: Experiment with grade-10 students using Silver Inquiry Approach". Paper published in : Journal of Science and Mathematics Teaching, GUNMA University, No, 59, 1-16, 2011

Widyaningtias,R., Kusumah, Y.S., Sumarmo, U. Sabandar, Y. (2017), “The Impact of Problem Based Problem to Senior High School Students' Mathematics Critical Thinking Ability". published in Journal of Mathematics Education, 6 (2).pp 107-116 